\title{
Ion Transport during Cholera-Induced Ileal Secretion in the Dog
}

\author{
William L. Moore, Jr., Fred A. Bieberdorf, Stephen G. Morawski, \\ Richard A. Finkelstein, and John S. Fordtran \\ From the Departments of Internal Medicine and Microbiology, The University \\ of Texas (Southwestern) Medical School at Dallas, Dallas, Texas 75235
}

A B S T RACT To assess the ion transport mechanism by which cholera causes the small bowel to secrete, ion transport rates and electrical potential difference (PD) were determined simultaneously in the normal and choleragen-treated dog ileum in vivo. The results indicate that, during cholera, $\mathrm{HCO}_{s}$ is actively secreted (i.e., against both an electrical and a concentration gradient); $\mathrm{Cl}$ is also actively secreted, against a modest electrochemical gradient. Electrogenic pumping of one or both of these anions is probably responsible for an observed $\mathrm{PD}$ change of approximately $13 \mathrm{mv}$ (lumen negative). $\mathrm{Na}$ secretion can be accounted for entirely by passive ion movement. $\mathrm{K}$ secretion can be partly explained by passive diffusion secondary to the negative intraluminal $\mathrm{PD}$; however, its concentration in the secreted fluid is two to three times higher than expected on the basis of passive forces, suggesting a component of active $K$ secretion. The $\mathrm{PD}$ response of the choleragen-treated ileum is normal in response to glucose, but there was no PD response to saline-free mannitol perfusion. This suggests that the normal differential permeability of the ileum to anions and cations may be altered by choleragen, although other explanations of this finding are also possible.

\section{INTRODUCTION}

The mechanism by which cholera causes the intestinal mucosa to secrete large volumes of fluid is unknown. Recent experimental results have been reviewed $(1,2)$; they have focused mainly on $\mathrm{Na}$ movement and have shown that fluid production originates in the small intestine, is isotonic to plasma, and is rich in $\mathrm{HCO}_{3}$ (compared with the bicarbonate concentration normally found in a particular area of the small intestine). The electrical potential difference (PD) across the secreting

Received for publication 30 June 1970 and in revised form 19 October 1970. intestine has not been correlated with ion secretion rates in vivo so that it is not known which ions, if any, are actively secreted and which ions move passively. The possibility of a fltration process has not been completely excluded although there is no direct evidence to support this hypothesis. This paper presents data on ion transport and PD, measured simultaneously, in the dog ileum during choleragen-induced secretion. The ileum was chosen for study because it, unlike the duodenum and jejunum, can develop and sustain large chemical and electrical gradients (3). Electrogenic or nonelectrogenic active transport might thus be easier to appreciate in the ileum than in higher regions of the small intestine.

\section{METHODS}

Studies were performed on dewormed and 18-hr fasted dogs weighing $10-20 \mathrm{~kg}$. Anesthesia was induced by i.v. sodium thiopental and maintained by urethane and chloralose. Respiration was controlled by an animal respirator. At laparotomy a $15-30 \mathrm{~cm}$ ileal loop was isolated, the distal end of which was $20 \mathrm{~cm}$ from the cecum. Teflon spools were inserted into the ends of the loop and tied in place. Continuity of the remaining ileum was restored by anastomosis. $175 \mathrm{ml}$ of a balanced electrolyte solution ( $\mathrm{Na} 135, \mathrm{~K} 5$, $\mathrm{Cl} 115$, and $\mathrm{HCO}_{3} 25 \mathrm{mEq} /$ liter, and $500 \mathrm{mg} / 100 \mathrm{ml}$ of polyethylene glycol [PEG], a nonabsorbable volume marker) was recirculated through the loop at a pump speed of 6 $\mathrm{ml} / \mathrm{min}$. Intraluminal pressure was kept constant at $4-5 \mathrm{~cm}$ of $\mathrm{H}_{2} \mathrm{O}$ by adjusting the fluid level in a reservoir connected to the distal end of the loop. After a 30-min equilibration period, a $3 \mathrm{ml}$ sample was removed and designated the zero time sample. Hourly samples were then taken for $11 \mathrm{hr}$.

To measure $\mathrm{PD}$, one end of an agar- $\mathrm{KCl}$ bridge was inserted into the distal end of the loop via the reservoir and its connecting tubing; the other end was placed in a beaker of saturated $\mathrm{KCl}$ solution. One of a matched pair of calomel half-cell electrodes was placed in the beaker of $\mathrm{KCl}$; the other was placed subcutaneously and the lumen-to-subcutaneous tissue PD measured with a Keithly $600 \mathrm{~B}$ electrometer (Keithly Instruments, Inc., Cleveland, Ohio). (Intravenous, peritoneal, and subcutaneous reference sites 
were compared in three dogs and showed no differences.) PD reported throughout refers to intraluminal potential with respect to subcutaneous tissue.

$100 \mu \mathrm{g}$ of choleragen (4) was added at zero time in the "cholera" studies. In two control studies, $100 \mu \mathrm{g}$ of choleragenoid, a natural, nontoxic toxoid of the cholera enterotoxin (4), was added at zero time. In three control experiments nothing was added.

Arterial blood pressure, $\mathrm{pH}, \mathrm{PCO}_{2}$, and serum concentrations of $\mathrm{Na}, \mathrm{K}, \mathrm{Cl}, \mathrm{HCO}_{3}$, and serum osmolality were monitored hourly. Electrolytes were measured by standard techniques, PEG by the method of Hyden (5), osmolality by freezing point depression, and $\mathrm{pH}$ and $\mathrm{PCO}_{2}$ by a Duomatic analyzer (Instrumentation Laboratory, Inc., Watertown, Mass.). Net water and solute movement was calculated by standard techniques (6). PEG recovery, measured at the end of the 7th and 11th hr in each study, was 100.5 $\pm 1.9 \%$ in the control and $99.6 \pm 0.9 \%$ in the choleragentreated dogs. Sections of control and choleragen-treated ileal loops, taken at the end of each study, revealed no histologic differences.

\section{RESULTS}

A typical control experiment is shown in Fig. 1. Water absorption continued throughout the first $7 \mathrm{hr}$ of re-

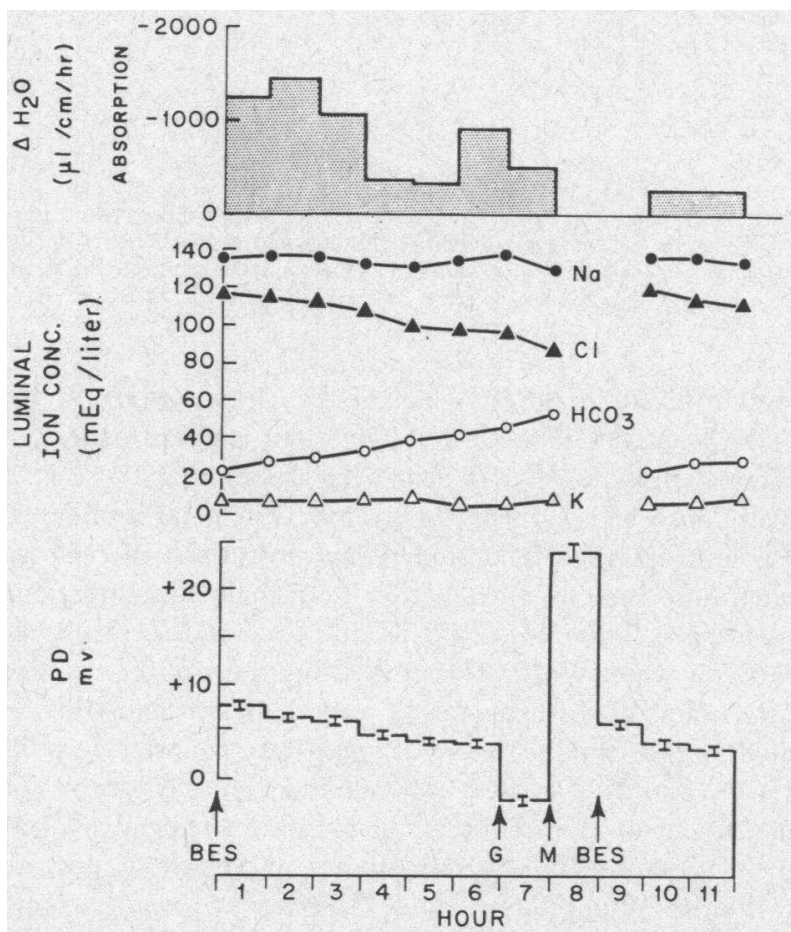

FIgURE 1 Representative experiment in a control dog. A balanced electrolyte solution (BES) was recirculated for the first $7 \mathrm{hr}$. Glucose (G) was added to BES at beginning of 7 th hr (glucose concentration approximately 50 mmoles/ liter). During the 8 th $\mathrm{hr}$, the loop was rinsed with isotonic mannitol (M). During the 9th hr, the loop was rinsed with BES. Recirculation of BES was resumed at the beginning of the 10th hr. The PD values are the mean \pm 1 SE of observations made every $2 \mathrm{~min}$.
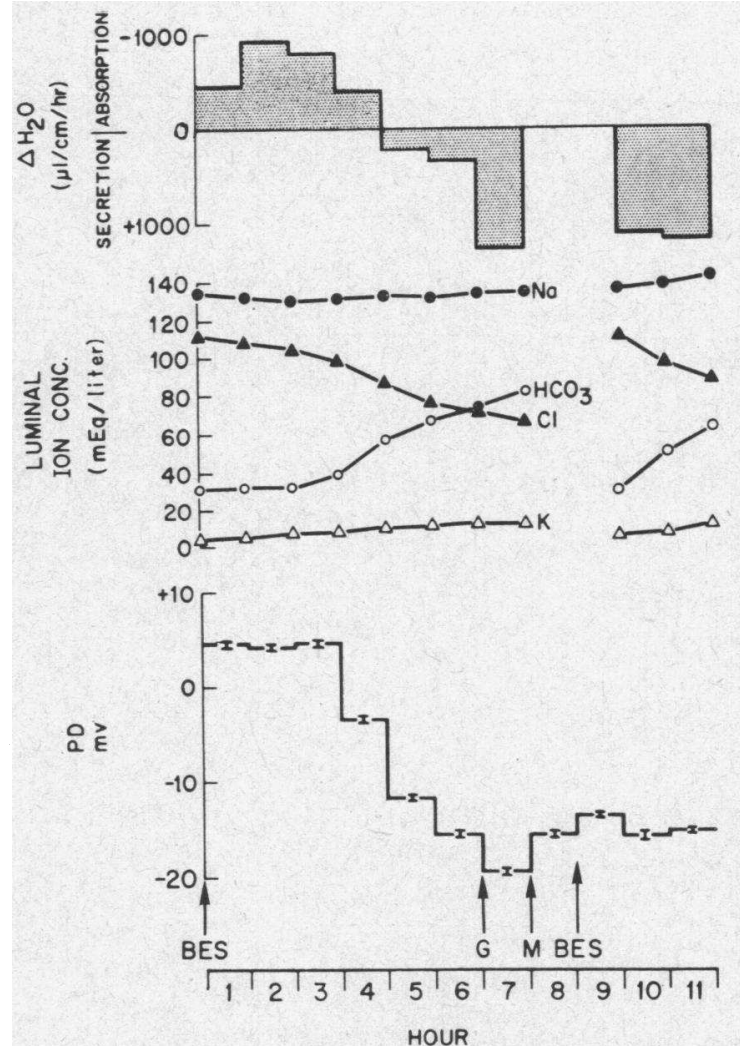

FIGURE 2 Representative experiment in a choleragen-treated dog. See legend in Fig. 1 for explanation of symbols.

circulation. The $\mathrm{Na}$ concentration of the recirculated fluid was between 130 and $135 \mathrm{mEq} /$ liter (serum Na 150); the $\mathrm{Cl}$ concentration fell to $85 \mathrm{mEq} /$ /iter (serum $\mathrm{Cl} 120$ 126). The $\mathrm{HCO}_{3}$ concentration rose from 21 to $52 \mathrm{mEq} /$ liter (serum $\mathrm{HCO}_{3} 20-22$ ). The $\mathrm{K}$ concentration rose from 4 to $5.5 \mathrm{mEq} /$ liter (serum $\mathrm{K} 3.5-4$ ). The PD was between +7 and $+4 \mathrm{mv}$ during the first $6 \mathrm{hr}$ of recirculation. Addition of glucose (in an amount calculated to achieve a $50 \mathrm{~mm}$ glucose solution) at the $7 \mathrm{th}$ hr caused the $\mathrm{PD}$ to become $-2.0 \mathrm{mv}$. Isotonic mannitol was perfused during the 8 th $\mathrm{hr}$, and the PD became $+23 \mathrm{mv}$. $A$ return to the electrolyte solution cause the $P D$ to return to its original level, and during a final $2 \mathrm{hr}$ period of recirculation, water absorption continued. Mean results in five similar studies, including net ion movement and osmolality at each hour, are shown in Table I.

Fig. 2 shows a typical study when choleragen was added to the perfusion fluid. Water was absorbed during the first $4 \mathrm{hr}$, and secretion was observed thereafter. The $\mathrm{Na}$ concentration was about $135 \mathrm{mEq} /$ liter in the recirculated fluid compared with serum $\mathrm{Na}$ of 143-148. The $\mathrm{Cl}$ concentration fell from 110 to $65 \mathrm{mEq} /$ liter (serum $\mathrm{Cl}$ 108-120). The $\mathrm{HCO}_{3}$ concentration rose from 29 to $80 \mathrm{mEq} / \mathrm{liter}$ (serum $\mathrm{HCO}_{3} 19-21$ ). $\mathrm{K}$ con- 
TABLE I

Mean Results in Control and

\begin{tabular}{|c|c|c|c|c|c|c|c|c|c|c|c|c|}
\hline & \multicolumn{4}{|c|}{ Blood or serum } & \multicolumn{8}{|c|}{ Luminal contents, $\mathrm{PD}$, and transport rates } \\
\hline & \multicolumn{2}{|c|}{ Initial } & \multicolumn{2}{|c|}{ Final } & \multicolumn{2}{|c|}{ hr 1} & \multicolumn{2}{|c|}{ hr 2} & \multicolumn{2}{|c|}{ hr 3} & \multicolumn{2}{|c|}{ hr 4} \\
\hline & $\begin{array}{l}\text { Con- } \\
\text { trol }\end{array}$ & $\begin{array}{l}\text { Chol- } \\
\text { era }\end{array}$ & $\begin{array}{l}\text { Con- } \\
\text { trol }\end{array}$ & $\begin{array}{c}\text { Chol- } \\
\text { era }\end{array}$ & $\begin{array}{c}\text { Con- } \\
\text { trol }\end{array}$ & $\begin{array}{c}\text { Chol- } \\
\text { era }\end{array}$ & $\begin{array}{l}\text { Con- } \\
\text { trol }\end{array}$ & $\begin{array}{c}\text { Chol- } \\
\text { era }\end{array}$ & $\begin{array}{c}\text { Con- } \\
\text { trol }\end{array}$ & $\begin{array}{c}\text { Chol- } \\
\text { era }\end{array}$ & $\begin{array}{c}\text { Con- } \\
\text { trol }\end{array}$ & $\begin{array}{c}\text { Chol- } \\
\text { era }\end{array}$ \\
\hline \multirow[t]{2}{*}{$\Delta \mathrm{H}_{2} \mathrm{O}$} & & & & & -1158 & -770 & -858 & -513 & -779 & +55 & -465 & +151 \\
\hline & & & & & \pm 150 & \pm 178 & \pm 180 & \pm 585 & \pm 143 & \pm 186 & \pm 83 & \pm 137 \\
\hline \multirow[t]{2}{*}{ Osmolality } & 304 & 302 & 312 & 308 & 264 & 268 & 266 & 270 & 266 & 273 & 269 & 276 \\
\hline & \pm 5 & \pm 5 & \pm 3 & \pm 4 & \pm 2 & \pm 4 & \pm 3 & \pm 2 & \pm 3 & \pm 2 & \pm 5 & \pm 2 \\
\hline \multirow[t]{2}{*}{ Na concentration } & 146 & 141 & 145 & 141 & 135 & 132 & 134 & 131 & 132 & 131 & 131 & 132 \\
\hline & \pm 1 & \pm 1 & \pm 3 & \pm 1 & \pm 1 & \pm 2 & \pm 2 & \pm 2 & \pm 3 & \pm 2 & \pm 4 & \pm 2 \\
\hline \multirow[t]{2}{*}{$\Delta \mathrm{Na}$} & & & & & -142 & -115 & -123 & -67 & -108 & +14 & -62 & +26 \\
\hline & & & & & \pm 21 & \pm 25 & \pm 26 & \pm 37 & \pm 20 & \pm 24 & \pm 12 & \pm 19 \\
\hline \multirow[t]{2}{*}{$\mathbf{K}$ concentration } & 3.3 & 2.9 & 3.6 & 3.3 & 5.3 & 7.3 & 5.6 & 8.0 & 6.0 & 9.6 & 6.5 & 10.6 \\
\hline & \pm 0.2 & \pm 0.2 & \pm 0.2 & \pm 0.1 & \pm 0.1 & \pm 1.7 & \pm 1.0 & \pm 1.6 & \pm 0.2 & \pm 2.1 & \pm 0.3 & \pm 2.2 \\
\hline \multirow{2}{*}{$\Delta \mathrm{K}$} & & & & & $-\quad 3.4$ & -1.4 & $-\quad 2.7$ & +1.0 & -2.6 & +5.0 & -1.3 & +4.5 \\
\hline & & & & & \pm 1.0 & \pm 0.6 & \pm 1.1 & \pm 1.4 & \pm 0.9 & \pm 0.6 & \pm 0.2 & \pm 1.7 \\
\hline \multirow[t]{2}{*}{$\mathrm{Cl}$ concentration } & 117 & 106 & 117 & 110 & 112 & 103 & 110 & 97 & 107 & 90 & 102 & 85 \\
\hline & \pm 2 & \pm 3 & \pm 3 & \pm 4 & \pm 2 & \pm 5 & \pm 2 & \pm 4 & \pm 3 & \pm 5 & \pm 5 & \pm 4 \\
\hline \multirow[t]{2}{*}{$\Delta \mathrm{Cl}$} & & & & & -132 & -108 & -104 & -74 & -102 & -18 & -57 & -6 \\
\hline & & & & & \pm 19 & \pm 23 & \pm 23 & \pm 28 & \pm 21 & \pm 2 & \pm 12 & \pm 18 \\
\hline \multirow[t]{2}{*}{$\mathrm{HCO}_{3}$ concentration } & 20 & 19 & 18 & 18 & 28 & 36 & 30 & 40 & 32 & 49 & 36 & 57 \\
\hline & \pm 1 & \pm 1 & \pm 2 & \pm 1 & \pm 1 & \pm 4 & \pm 1 & \pm 4 & \pm 2 & \pm 5 & \pm 1 & \pm 5 \\
\hline \multirow[t]{2}{*}{$\triangle \mathrm{HCO}_{3}$} & & & & & -9 & -11 & -20 & +9 & -12 & +36 & -6 & +33 \\
\hline & & & & & \pm 4 & \pm 3 & \pm 4 & \pm 13 & \pm 5 & \pm 7 & \pm 2 & \pm 8 \\
\hline \multirow[t]{2}{*}{ PD } & & & & & $+\quad 2.5$ & $+\quad 0.8$ & +2.6 & $-\quad 2.1$ & +2.3 & -6.0 & +1.9 & -8.8 \\
\hline & & & & & \pm 1.6 & \pm 1.7 & \pm 1.4 & \pm 2.7 & \pm 1.2 & \pm 2.7 & \pm 1.0 & \pm 1.8 \\
\hline \multirow[t]{2}{*}{$\mathrm{pH}$} & 7.45 & 7.40 & 7.39 & 7.37 & & & & & & & & \\
\hline & \pm 0.02 & \pm 0.02 & \pm 0.01 & \pm 0.02 & & & & & & & & \\
\hline \multirow[t]{2}{*}{$\mathrm{PcO}_{2}$} & 33 & 34 & 31 & 35 & & & & & & & & \\
\hline & \pm 2 & \pm 2 & \pm 2 & \pm 2 & & & & & & & & \\
\hline
\end{tabular}

* A balanced electrolyte solution was recirculated for the first 6 and final $2 \mathrm{hr}$. During hr 7 glucose was added. Isotonic mannitol was perfused during $\mathrm{hr}$. The loop was rinsed with the electrolyte solution during hr 9 . Units are $\mu \mathrm{l} / \mathrm{cm}$ per hr for $\Delta \mathrm{H}_{2} \mathrm{O}$. $\mu \mathrm{Eq} / \mathrm{cm} \mathrm{per} \mathrm{hr} \mathrm{for} \Delta$ ion movement, $\mathrm{mOsm} / \mathrm{kg}$ for osmolality, $\mathrm{mv}$ for $\mathrm{PD}$, and $\mathrm{mm} \mathrm{Hg}$ for PCO2. A minus sign denotes absorption, a positive sign denotes secretion. Values given are the mean \pm 1 SE of five control and six choleragen-treated dogs.

centration rose from 5 to $13 \mathrm{mEq} /$ liter (serum $\mathrm{K} \mathrm{3.0-}$ 3.9). $\mathrm{PD}$ was approximately $+4 \mathrm{mv}$ for the first $3 \mathrm{hr}$, and fell thereafter, reaching a level of $-16 \mathrm{mv}$ in the $6 \mathrm{th} \mathrm{hr}$. Addition of glucose caused the PD to become more negative to $-20 \mathrm{mv}$. Perfusion of isotonic mannitol caused the PD to return to the level observed with the electrolyte solution. (Thus, the PD response of the choleragen-treated ileum is normal in response to glucose but abnormal in response to isotonic mannitol perfusion.) When a balanced electrolyte solution was rinsed through the loop during the 9th $\mathrm{hr}$, the PD was $-14 \mathrm{mv}$; during 2 final $\mathrm{hr}$ of recirculation, fluid secretion continued, and the PD was $-16 \mathrm{mv}$.

Mean results in six similar studies are shown in Table I. Choleragen caused a secretion of all measured electrolytes, and the osmolality of recirculated fluid remained less than that of serum.

\section{DISCUSSION}

When a balanced electrolyte solution was recirculated for a period of hours through the normal ileum, the fluid developed a lower $\mathrm{Na}$ and $\mathrm{Cl}$ concentration than the serum levels of these electrolytes. Absorption of $\mathrm{Na}$ and $\mathrm{Cl}$ associated with a fall in their concentrations in luminal fluid and a PD near zero means that these ions were absorbed against their electrochemical gradients. By contrast, the $\mathrm{HCO}_{3}$ and $\mathrm{K}$ concentrations in recirculated fluid rose to levels higher than their concentrations in plasma. This rise could be due to a relatively higher rate of water absorption than the absorption rate of $\mathrm{HCO}_{s}$ and $\mathrm{K}$, with the result that their concentration in unabsorbed fluid rises. Although active transport of $\mathrm{HCO}_{3}$ and $\mathrm{K}$ has not been excluded, no evidence for movement of these ions against an electrochemical gradient was observed in our studies. Addition of glucose to luminal fluid caused the PD to become negative and perfusion of isotonic mannitol caused the $\mathrm{PD}$ to become markedly positive (compatible with a $\mathrm{Na}$ diffusion potential). These results in normal dogs are similar to those obtained in the human ileum studied by a perfusion technique and are in accord with an anion and cation exchange model proposed for normal ileal absorption (7). The results are also compatible with the model of Shultz and Curran wherein electrogenic $\mathrm{Na}$ 


\begin{tabular}{|c|c|c|c|c|c|c|c|c|c|c|c|c|c|}
\hline \multicolumn{14}{|c|}{ Luminal contents, $\mathrm{PD}$, and transport rates } \\
\hline \multicolumn{2}{|c|}{ hr 5} & \multicolumn{2}{|c|}{ hr 6} & \multicolumn{2}{|c|}{$\begin{array}{c}\text { hr } 7 \\
\text { (Glucose) }\end{array}$} & \multicolumn{2}{|c|}{$\begin{array}{c}\text { hr } 8 \\
\text { (Mannitol) }\end{array}$} & \multicolumn{2}{|c|}{ hr 9} & \multicolumn{2}{|c|}{ hr 10} & \multicolumn{2}{|c|}{ hr 11} \\
\hline $\begin{array}{c}\text { Con- } \\
\text { trol }\end{array}$ & $\begin{array}{c}\text { Chol- } \\
\text { era }\end{array}$ & $\begin{array}{l}\text { Con- } \\
\text { trol }\end{array}$ & $\begin{array}{c}\text { Chol- } \\
\text { era }\end{array}$ & $\begin{array}{c}\text { Con- } \\
\text { trol }\end{array}$ & $\begin{array}{c}\text { Chol- } \\
\text { era }\end{array}$ & $\begin{array}{l}\text { Con- } \\
\text { trol }\end{array}$ & $\begin{array}{c}\text { Chol- } \\
\text { era }\end{array}$ & $\begin{array}{c}\text { Con- } \\
\text { trol }\end{array}$ & $\begin{array}{c}\text { Chol- } \\
\text { era }\end{array}$ & $\begin{array}{c}\text { Con- } \\
\text { trol }\end{array}$ & $\begin{array}{c}\text { Chol- } \\
\text { era }\end{array}$ & $\begin{array}{c}\text { Con- } \\
\text { trol }\end{array}$ & $\begin{array}{c}\text { Chol- } \\
\text { era }\end{array}$ \\
\hline-359 & +316 & -529 & +626 & -319 & +1272 & & & & & -259 & +1127 & -161 & +724 \\
\hline \pm 85 & \pm 84 & \pm 115 & \pm 256 & \pm 46 & \pm 217 & & & & & \pm 25 & \pm 495 & \pm 43 & \pm 196 \\
\hline 270 & 280 & 269 & 285 & 285 & 296 & & & & & 268 & 272 & 275 & 282 \\
\hline \pm 5 & \pm 3 & \pm 6 & \pm 3 & \pm 12 & \pm 6 & & & & & \pm 1 & \pm 2 & \pm 2 & \pm 3 \\
\hline 130 & 132 & 130 & 133 & 128 & 135 & & & & & 134 & 135 & 135 & 136 \\
\hline \pm 4 & \pm 2 & \pm 4 & \pm 2 & \pm 3 & \pm 2 & & & & & \pm 1 & \pm 1 & \pm 1 & \pm 2 \\
\hline-51 & +44 & -66 & +88 & -55 & +177 & & & & & -34 & +154 & -20 & +104 \\
\hline \pm 14 & \pm 13 & \pm 14 & \pm 34 & \pm 8 & \pm 33 & & & & & \pm 4 & \pm 71 & \pm 7 & \pm 30 \\
\hline 6.7 & 12.0 & 7.0 & 13.1 & 7.7 & 14.3 & & & & & 6.3 & 7.1 & 7.6 & 8.8 \\
\hline \pm 0.5 & \pm 2.5 & \pm 0.8 & \pm 2.5 & \pm 0.9 & \pm 2.5 & & & & & \pm 0.5 & \pm 0.5 & \pm 0.7 & \pm 0.8 \\
\hline$-\quad 0.8$ & +6.5 & $-\quad 1.5$ & +10.8 & +0.4 & +23.3 & & & & & +2.4 & +15.3 & +4.2 & +11.9 \\
\hline \pm 0.6 & \pm 1.5 & \pm 1.1 & \pm 3.0 & \pm 0.7 & \pm 3.0 & & & & & \pm 1.4 & \pm 6.0 & \pm 3.0 & \pm 2.0 \\
\hline 97 & 79 & 93 & 75 & 88 & 70 & & & & & 113 & 102 & 110 & 93 \\
\hline \pm 6 & \pm 5 & \pm 8 & \pm 5 & \pm 6 & \pm 4 & & & & & \pm 2 & \pm 1 & \pm 3 & \pm 1 \\
\hline-49 & +3 & -56 & +35 & -53 & +58 & & & & & -34 & +73 & -29 & +42 \\
\hline \pm 16 & \pm 9 & \pm 9 & \pm 17 & \pm 9 & \pm 1 & & & & & \pm 8 & \pm 37 & \pm 6 & \pm 13 \\
\hline 40 & 64 & 44 & 69 & 48 & 77 & & & & & 28 & 37 & 33 & 50 \\
\hline \pm 2 & \pm 5 & \pm 4 & \pm 5 & \pm 4 & \pm 4 & & & & & \pm 2 & \pm 3 & \pm 3 & \pm 4 \\
\hline$-\quad 2.0$ & +43 & +9 & +60 & -4 & +138 & & & & & +4 & +94 & +15 & +82 \\
\hline \pm 2 & \pm 8 & \pm 8 & \pm 20 & \pm 3 & \pm 21 & & & & & \pm 8 & \pm 42 & \pm 8 & \pm 17 \\
\hline$+\quad 1.5$ & -11.0 & $+\quad 1.1$ & -13.2 & -4.0 & $-\quad 19.0$ & +35.0 & -15.0 & +1.0 & -14.0 & $+\quad 0.5$ & $-\quad 14.4$ & 0.0 & -15.3 \\
\hline \pm 1.1 & \pm 1.4 & \pm 0.9 & \pm 1.4 & \pm 0.8 & \pm 1.5 & \pm 7.0 & \pm 1.0 & \pm 1.0 & \pm 1.1 & \pm 1.2 & \pm 1.4 & \pm 1.0 & \pm 0.7 \\
\hline
\end{tabular}

and $\mathrm{Cl}$ absorption occur at equal rates so that no $\mathrm{PD}$ develops (8).

As noted previously by Visscher (9), fluid recirculated through the normal dog ileum always developed an osmolality lower than that in plasma; in one of our dogs the osmolality of luminal contents fell to $240 \mathrm{mOsm} / \mathrm{kg}$ compared with a blood osmolality of $300 \mathrm{mOsm} / \mathrm{kg}$. These results are compatible with passive water movement secondary to active ion transport and suggest that the permeability of ileal mucosa to bulk water flow is sufficiently low that passive water transport cannot keep pace with active solute absorption.

The ileum exposed to choleragen behaved quite differently than the controls. Fluid secretion usually began in the 3rd hr after choleragen was added to ileal fluid and was associated with the development of a lumennegative $\mathrm{PD}$ of about $13 \mathrm{mv}$. During choleragen-induced secretion, luminal fluid developed $\mathrm{HCO}_{3}$ and $\mathrm{K}$ concentrations higher than their serum concentrations, while the $\mathrm{Cl}$ cncentration fell far below its serum concentration.
As shown by the cholera data in Table $\mathrm{I}, \mathrm{HCO}_{3}$ is secreted against both an electrical and a chemical concentration gradient; and since its concentration in the recirculated fluid rose steadily and to levels higher than serum $\mathrm{HCO}_{3}$, solvent drag cannot be responsible for its movement against this steep gradient $(3,10)$. According to standard definitions (10), $\mathrm{HCO}_{3}$ movement in cholera may therefore be said to be active. ${ }^{1}$ By contrast, $\mathrm{Na}$ movement can be attributed entirely to passive diffusion in response to the lumen-negative PD.

$\mathrm{Cl}$ secretion was against an electrochemical gradient as defined by the Nernst equation (10). This is made evident most clearly in the 10 th $\mathrm{hr}$ study period. In spite of a PD of $-14.4 \mathrm{mv}$, which would favor absorption, and a lumen $\mathrm{Cl}$ concentration close to that in plasma, $\mathrm{Cl}$ was secreted. It is unlikely that this resulted from solvent drag (10) since, in the human at least (3), passive permeability in the ileum is so slight that sol-

\footnotetext{
${ }^{1}$ Secretion of $\mathrm{HCO}_{3}$ might arise from secretion of $\mathrm{HCO}_{3}$ ions or absorption of $\mathrm{H}$ ions. $\mathrm{HCO}_{3}$ secretion in the text is used loosely to indicate net accumulation within the lumen achieved by one of these processes.
} 
vent drag is not a significant force for $\mathrm{NaCl}$ movement. However, solvent drag might be a more important force in the choleragen-treated ileum since anion and/or cation permeability is possibly altered (see below). It is also possible that the high $\mathrm{HCO}_{3}$ concentration in luminal fluid may have stimulated passive $\mathrm{Cl}$ secretion via an anion exchange (7), but this cannot be the major explanation for $\mathrm{Cl}$ secretion since $\mathrm{Cl}$ was secreted at a brisk rate in hr 10, when a fresh solution (with a bicarbonate concentration of only $25 \mathrm{mEq} /$ liter) was perfused.

To some extent $\mathrm{K}$ secretion can be attributed to the lumen-negative $P D$, although the $K$ concentration in recirculated fluid (6th $\mathrm{hr}$, for instance) is 2.4 times higher than predicted for passive transport by the Nernst equation (10). This suggests active $\mathrm{K}$ transport.

To summarize our interpretation of these experiments, choleragen elicits active $\mathrm{HCO}_{3}$ and $\mathrm{Cl}$ secretion; the transport of one or both of these anions is electrogenic causing the lumen to become negatively charged. ${ }^{2}$ All $\mathrm{Na}$ secretion is passive in response to the negative intraluminal $\mathrm{PD} . \mathrm{K}$ is secreted passively in response to the negative $\mathrm{PD}$, but its concentration in the secreted fluid is higher than expected if its movement were entirely passive, suggesting a component of active $\mathrm{K}$ secretion. The importance of $\mathrm{K}$ secretion is emphasized by the observation that this cation is secreted as early as the 2nd hr, before the onset of $\mathrm{H}_{2} \mathrm{O}$ or $\mathrm{Na}$ secretion.

The possibility that cholera secretion is caused by filtration related to an increased pressure in the microcirculation and/or an increased mucosal interstitial pressure has been entertained by some previous workers (12). We have previously argued, on theoretical basis, that filtration is an unlikely mechanism for gut secretion in cholera unless permeability of the gut is markedly increased (13), which does not seem to be the case since the ratio of the diffusion rates of $u r e a-{ }^{14} \mathrm{C}$ and arabinose- ${ }^{8} \mathrm{H}$ from plasma to gut lumen is not significantly altered during experimental cholera in the dog ileum. ${ }^{3}$ Furthermore, it has recently been shown that marked reduction in mesenteric blood flow does not significantly reduce gut secretion in response to cholera toxin (14). This also argues against filtration as an important mechanism of gut secretion in cholera. There are two additional reasons for believing that filtration was not a major factor in the etiology of the secretion that occurred after exposure of the ileal mucosa to choleragen. First, a filtration process could not explain

\footnotetext{
2 A change in tissue resistance could change the absolute level of transmembrane PD without a change in ion transport (11). However, an alteration in resistance could not change the orientation of PD from plus in controls to strongly minus in cholera.

${ }^{3}$ Unpublished data from our laboratory.
}

the concentration gradients of $\mathrm{HCO}_{3}, \mathrm{Cl}$, and $\mathrm{K}$, which we observed. Second, a filtration process could not explain the high lumen-negative $\mathrm{PD}$ which developed across the ileal mucosa.

Although both $\mathrm{HCO}_{3}$ and $\mathrm{Cl}$ are actively secreted, $\mathrm{HCO}_{s}$ transport appears to be of greater importance in the generation of fluid production, especially in the first few hours after exposure to choleragen. For instance, $\mathrm{HCO}_{3}$ is secreted at higher rates and against steeper electrochemical gradients than is $\mathrm{Cl}$, and for the first $2 \mathrm{hr}$ after the onset of fluid secretion, $\mathrm{Cl}$ is absorbed rather than secreted ( $\mathrm{hr} 3$ and 4, Table I). However, this does not necessarily mean that choleragen stimulates $\mathrm{HCO}_{3}$ secretion to a greater extent than $\mathrm{Cl}$ secretion, since it is possible that normal nonelectrogenic $\mathrm{Cl}$ absorption (as $\mathrm{NaCl}$ ) may have continued during cholera, thus partially obscuring the cholera-induced $\mathrm{Cl}$ secretion. The fact that the rate of fall in $\mathrm{Cl}$ absorption paralleled the rate of increase in $\mathrm{HCO}_{\mathbf{s}}$ secretion during the early hours of our experiment (Table I) lends weight to this suggestion. Using the $1 \mathrm{hr}$ values in the cholera group (Table I) as the normal absorption rate for these ileal loops and assuming this to remain constant for the first $6 \mathrm{hr}$ of the experiment, the calculated anion makeup (total anion concentration assumed to be $140 \mathrm{mEq} /$ liter) of the cholera-induced secretion is 86-98 $\mathrm{mEq} /$ liter of $\mathrm{Cl}$ and $42-54 \mathrm{mEq} / \mathrm{liter}$ of $\mathrm{HCO}_{3}$. Similar values were calculated for $\mathrm{hr} 10$ and 11 , but for $\mathrm{hr} 7$, when glucose was added to luminal fluid, relatively more $\mathrm{HCO}_{3}(66 \mathrm{mEq} /$ liter $)$ and less $\mathrm{Cl}(74 \mathrm{mEq} /$ liter) was present in this calculated secretion. The significance of this apparent effect of glucose is not clear.

Our finding that the PD becomes negative in the dog ileum during cholera is in disagreement with a recent study by Sachar, Taylor, Saha, and Phillips (15). These workers found jejunal and ileal PD to be normal in seven cholera patients who were rehydrated but still had diarrhea. Unfortunately, water and ion transport rates in the small bowel of these subjects were not studied, and it is not known whether or not the ileal segments under study were actually secreting fluid at the time PD measurements were made. On the other hand, Field, Fromm, Wallace, and Greenough (16) and Moritz, Moore, Grady, and Iber (17) have reported small (3 and $2 \mathrm{mv}$ ) lumen-negative transmural PD's in in vivo rabbit small intestine exposed to cholera toxin, and the development of this PD was found to correlate with onset of fluid secretion. Ion flux measurements were not reported so a distinction of which ions are actively and which are passively secreted in the rabbit in vivo is not available from these preliminary reports.

While the results presented here obviously cannot be extrapolated directly to secretion induced by cholera toxin in the duodenum and jejunum, the mechanisms 
proposed for the ileum are compatible with previous observations made in the upper small bowel, provided account is taken of the normal difference in ion transport and permeability between the upper and lower small intestine. Thus, although fluid collected from the duodenum and jejunum of cholera-treated animals has a $\mathrm{HCO}_{3}$ concentration only slightly higher than plasma $(1,2,18)$, such levels are much higher than the $\mathrm{HCO}_{3}$ concentration of fluid which is allowed to equilibrate with the normal upper small bowel (19). The failure of $\mathrm{HCO}_{3}$ concentration in jejunal fluid to rise to the high concentrations noted when the ileum is exposed to cholera toxin might be explained by $\mathrm{H}$ secretion, which we believe occurs normally in the proximal small intestine (20). If this normal mechanism persisted during cholera, $\mathrm{HCO}_{3}$ secretion in response to cholera would be partially dissipated by its reaction with $\mathrm{H}$. Furthermore, active $\mathrm{Cl}$ absorption does not normally occur in the proximal small bowel $(3,20)$, so persistence of normal absorption mechanisms would not result in a chloride impoverishment of jejunal contents. Hence, it is not surprising that jejunal fluid during cholera has $\mathrm{Cl}$ and $\mathrm{HCO}_{3}$ concentrations close to that of plasma $(1,2,18)$. Finally, steep concentration gradients are unlikely under any circumstances across the upper small bowel because of the high degree of its passive permeability to water, $\mathrm{Na}, \mathrm{Cl}$, and $\mathrm{K}(3)$. On the other hand, the proximal small bowel is relatively impermeable to $\mathrm{HCO}_{3}(3)$, so that concentration gradients might be generated were this ion to be actively secreted; as already noted, however, the normal process of $\mathrm{H}$ secretion might partially mask $\mathrm{HCO}_{3}$ secretion.

Active $\mathrm{HCO}_{3}, \mathrm{Cl}$, and $\mathrm{K}$ secretion cannot be explained readily in terms of an alteration of normal ion transport. One model of normal ileal transport does not include anything about active $\mathrm{HCO}_{3}$ movement (8); another predicts and explains active $\mathrm{HCO}_{3}$ and $\mathrm{Cl}$ secretion under some circumstances, but this model involves a coupled anion and cation exchange (7), and thus, does not explain the generation of a PD by ion transport. Neither model explains active $\mathrm{K}$ secretion. It seems likely, therefore, that cholera toxin either initiates a new transport system that is not present normally or stimulates a transport system that normally is small and undetectable.

Recently Field et al. (16) and Al-Awqati, Cameron, Field, and Greenough (21) have published abstracts dealing with the effect of cholera toxin on ion transport by in vitro rabbit and human ileal mucosa, respectively. They concluded that ileal fluid loss resulted primarily from stimulation of active $\mathrm{Cl}$ secretion. There was apparently no evidence of active $\mathrm{HCO}_{3}$ or $\mathrm{K}$ secretion. There thus may be a discrepancy between the effects of cholera toxin in vitro and in vivo.
Normally, when isotonic mannitol is perfused through the ileum the PD becomes strongly lumen positive; this has been interpreted to mean that ileal mucosa is more permeable to cations than to anions (7). A remarkable finding of our cholera experiments is that mannitol perfusion does not alter PD. This suggests either that ileal mucosa during cholera loses its selective permeability to anions and cations or that the ileal permeability barrier is exposed only to the secreted fluid and does not "see" the low level of $\mathrm{Na}$ and $\mathrm{Cl}$ in the luminal contents during mannitol perfusion. If failure of the PD to respond to mannitol indicates an abnormality in ion permeability, this might be caused by enhanced anion or decreased cation permeability; either could theoretically play a role in the pathogenesis of cholera.

The significance of the PD response to glucose during cholera is not clear since the mechanism of this response in the normal ileum is controversial (7).

A final point of interest is the observation that luminal contents remained hypotonic to serum during cholerageninduced secretion. While the data are most likely explained by delayed osmotic adjustment of the slightly hypotonic fluid originally recirculated, the possibility of a hypotonic secretion cannot be ruled out. Hypotonic secretion could result from a special arrangement of membranes in series as described by Patlak, Goldstein, and Hoffman (22).

\section{ACKNOWLEDGMENTS}

The authors express their appreciation to Earl C. Smith who worked on this project during a summer student fellowship. Sue Adams and Martha Walke provided excellent technical assistance.

This study was supported by U. S. Public Health Service Grants 5 R01 AM 06506, 5 T01 AM 05490, and 5 T01 AI 00030 from the National Institutes of Health.

\section{REFERENCES}

1. Carpenter, C. C. J., R. B. Sack, J. C. Feeley, and R. W. Steenberg. 1968. Site and characteristics of electrolyte loss and effect of intraluminal glucose in experimental canine cholera. J. Clin. Invest. 47: 1210.

2. Iber, F. L., T. McGonagle, H. A. Serebro, E. Luebbers, T. M. Bayless, and T. R. Hendrix. 1969. Unidirectional sodium flux in small intestine in experimental canine cholera. Amer. J. Med. Sci. 258: 340.

3. Fordtran, J. S., F. C. Rector, Jr., and N. W. Carter. 1968. The mechanisms of sodium absorption in the human small intestine. J. Clin. Invest. 47: 884.

4. Finkelstein, R. A., and J. J. LoSpalluto. 1969. Patho. genesis of experimental cholera: preparation and isolation of choleragen and choleragenoid. J. Exp. Med. 130: 185.

5. Hyden, S. 1955. A turbidometric method for the determination of higher polyethylene glycols in biological materials. Landbruks-Hoegsk. Ann. 22: 139.

6. Fordtran, J. S. 1966. Marker perfusion techniques for measuring intestinal absorption in man. Gastroenterology. 51: 1089. 
7. Turnberg, L. A., F. A. Bieberdorf, S. G. Morawski, and J. S. Fordtran. 1970. Interrelationships of chloride, bicarbonate, sodium, and hydrogen transport in the human ileum. J. Clin. Invest. 49: 557.

8. Schultz, S. G., and P. F. Curran. 1968. Intestinal absorption of sodium chloride and water. In Handbook of Physiology. American Physiological Society, Washington, D. C. 3(6) : 1245 .

9. Visscher, M. B. 1957. Transport of water and electrolyte across intestinal epithelia. In Metabolic Aspects of Transport Across Cell Membranes. Q. R. Murphy, editor. University of Wisconsin Press, Madison, Wis. 57.

10. Ussing, H. H. 1960. The alkali metal ions in isolated systems and tissues. In Handbuch der Experimentellen Pharmakologie. Springer-Verlag, Berlin. 13: Pt. 1.

11. Schultz, S. G., P. F. Curran, and E. M. Wright. 1967. Interpretation of hexose-dependent electrical potential differences in small intestine. Nature (London). 214: 509.

12. Hakim, A. A., and N. Lifson. 1969. Effect of pressure on water and solute transport by dog intestinal mucosa in vitro. Amer. J. Physiol. 216: 276.

13. Fordtran, J. S. 1967. Speculations on the pathogenesis of diarrhea. Fed. Proc. 26: 1405.

14. Carpenter, C. C. J., W. B. Greenough, III, and R. B. Sack. 1969. The relationship of superior mesenteric artery blood flow to gut electrolyte loss in experimental cholera. J. Infec. Dis. 119: 182.
15. Sachar, D. B., J. O. Taylor, J. R. Saha, and R. A Phillips. 1969. Intestinal transmural electric potential and its response to glucose in acute and convalescent cholera. Gastroenterology. 56: 512.

16. Field, M., D. Fromm, C. K. Wallace, and W. B. Greenough, III. 1969. Stimulation of active chloride secretion in small intestine by cholera exotoxin. J. Clin. Invest. 48: 24a. (Abstr.)

17. Moritz, M., E. W. Moore, G. F. Grady, and F. L. Iber. 1970. Linear relationship between fluid production induced by cholera toxin and transmural potential difference. Fed. Proc. 29: 530. (Abstr.)

18. Carpenter, C. C. J., and W. B. Greenough, III. 1968 Response of the canine duodenum to intraluminal challenge with cholera exotoxin. J. Clin. Invest. 47: 2600.

19. Swallow, J. H., and C. F. Code. 1967. Intestinal transmucosal fluxes of bicarbonate. Amer. J. Physiol. 212: 717.

20. Turnberg, L. A., J. S. Fordtran, N. W. Carter, and F. C. Rector, Jr. 1970. Mechanism of bicarbonate absorption and its relationship to sodium transport in the human jejunum. J. Clin. Invest. 49: 548.

21. Al-Awqati, Q., J. L. Cameron, M. Field, and W. B. Greenough, III. 1970. Response of human ileal mucosa to choleragen and theophylline. J. Clin. Invest. 49: 2a. (Abstr.)

22. Patlak, C. S., D. A. Goldstein, and J. F. Hoffman. 1963. The flow of solute and solvent across a two-membrane system. J. Theor. Biol. 5: 426. 